\title{
Endocrinology through an endoscope: lesions in the esophagus, stomach, and duodenum in gastrinoma
}

- Fig. 1 shows the upper endoscopy of a 58-year-old man who was admitted for persistent gastrointestinal bleeding, which eventually required angiography with coiling of the side branches of the pancreaticoduodenal artery.

He had been using rabeprazole $(20 \mathrm{mg} /$ day) for gastroesophageal reflux disease since 2007. Although a single duodenal ulcer usually requires no further testing, the severity of the bleeding and the extent of the lesions warranted further investigation. Additional tests - serum gastrin (1500 ng/L, normal < $115 \mathrm{ng} / \mathrm{L}$ ), chromogranin A $(1150 \mu \mathrm{g} / \mathrm{L}$, normal < $94 \mu \mathrm{g} / \mathrm{L})$, a positive secretin stimulation test (serum gastrin $5251 \mathrm{ng} / \mathrm{L} 10$ minutes after an intravenous $2 \mathrm{U} / \mathrm{kg}$ bolus), and somatostatin receptor scintigraphy and endoscopic ultrasound ( $\bullet$ Fig. 2 ) - suggested a gastrinoma.

Other possibilities were excluded by appropriate tests, including Helicobacter pylori, drug-associated causes, vasculitis, ischemia, herpes simplex, and cytomegalovirus. Computed tomography did not identify the lesion shown in Fig. 2 or any metastases. During surgery, a palpable lesion near the pancreas was enucleated. Pathological analysis confirmed a peripancreatic lymph node gastrinoma.

This case illustrates the following points. First, fundic gland polyps are a less recognized but diagnostically useful manifestation of gastrinoma [1]. Although longterm proton-pump inhibitor therapy can also cause gastric fundic gland polyposis, this manifestation is usually not so elaborate as observed here ( Fig. 1) [2]. Second, relying on these and other more subtle manifestations may become increasingly important with the widespread use of proton-pump inhibitors, which may mask symptoms and delay diagnosis [3], as in our case. Third, the secretin stimulation test remains essential to differentiate gastrinoma from hypergastrinemia due to proton-pump inhibitors, although a falsepositive test was recently reported [4]. Finally, our case reiterates the usefulness of somatostatin receptor scintigraphy and endoscopic ultrasound in the preoperative work-up of gastrinoma [5].
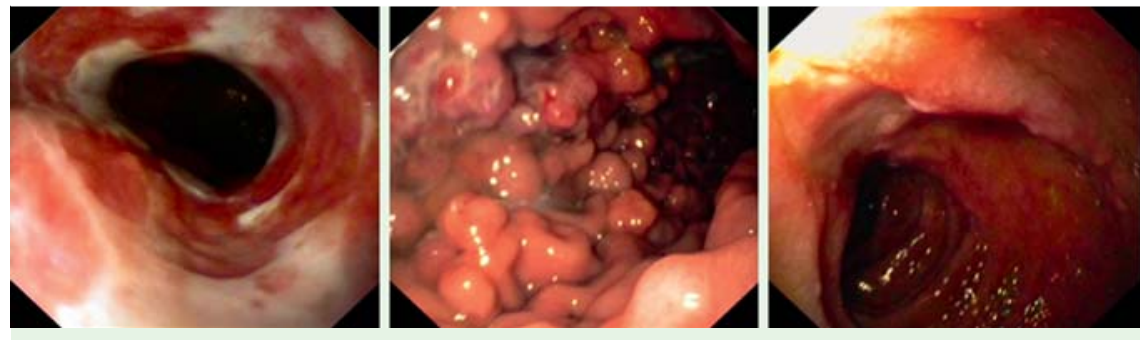

Fig. 1 Endoscopic view of a the esophagus, $\mathbf{b}$ the stomach, and $\mathbf{c}$ the duodenum, showing severe reflux esophagitis, multiple fundic gland polyps, and a single ulcer in the descending part of the duodenum.

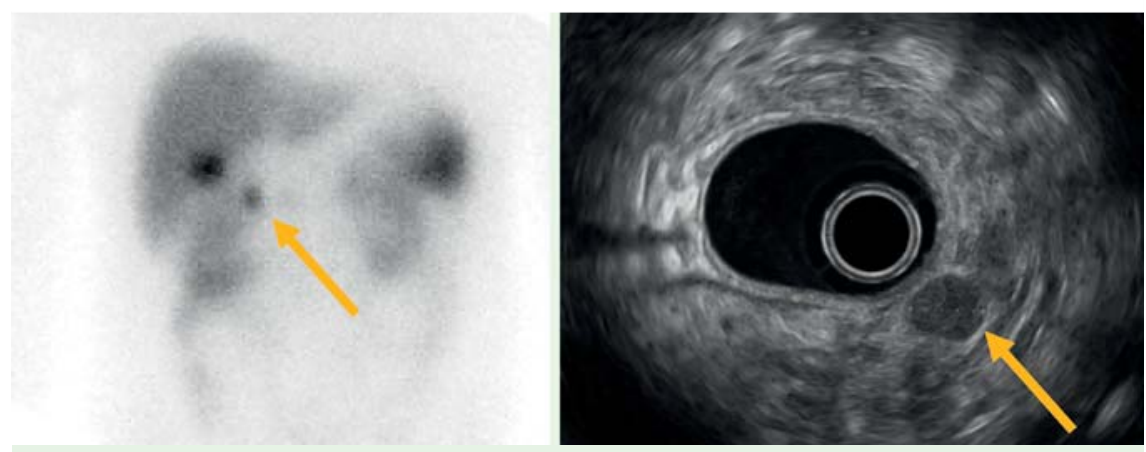

Fig. 2 Preoperative images of the peripancreatic lymph node gastrinoma as visualized by a somatostatin receptor scintigraphy and $\mathbf{b}$ endoscopic ultrasound.

\section{Competing interests: None}

E. J. Hoorn ${ }^{1}$, H. Aktas ${ }^{2}$, R. K. Linskens ${ }^{3}$, E. J. Kuipers ${ }^{1,2}$, P. B. Mensink ${ }^{2}$

1 Department of Internal Medicine, Erasmus Medical Center, Rotterdam, The Netherlands

2 Department of Gastroenterology and Hepatology, Erasmus Medical Center, Rotterdam, The Netherlands

3 Department of Gastroenterology, St Anna Hospital, Geldrop, The Netherlands

\section{References}

1 Aprile MR, Azzoni C, Gibril F et al. Intramucosal cysts in the gastric body of patients with Zollinger-Ellison syndrome. Hum Pathol 2000; $31: 140-148$

2 Freeman HJ. Proton pump inhibitors and an emerging epidemic of gastric fundic gland polyposis. World J Gastroenterol 2008; 14: $1318-1320$

3 Wong H, Yau T, Chan P et al. PPI-delayed diagnosis of gastrinoma: oncologic victim of pharmacologic success. Pathol Oncol Res 2010; 16: 87-91
4 Goldman JA, Blanton WP, Hay DW et al. Falsepositive secretin stimulation test for gastrinoma associated with the use of proton pump inhibitor therapy. Clin Gastroenterol Hepatol 2009; 7: 600-602

5 Zimmer T, Stölzel $U$, Bäder $M$ et al. Endoscopic ultrasonography and somatostatin receptor scintigraphy in the preoperative localisation of insulinomas and gastrinomas. Gut 1996; 39: $562-568$

Bibliography

DOI $10.1055 / \mathrm{s}-0030-1256028$

Endoscopy 2011; 43: E32

(c) Georg Thieme Verlag KG Stuttgart · New York . ISSN 0013-726X

\section{Corresponding author}

\section{E. J. Hoorn, MD, PhD}

Erasmus Medical Center, Room D-406

PO Box 2040

3000 CA Rotterdam

The Netherlands

Fax: +31-10-4366372

ejhoorn@gmail.com 